\title{
LASIOCOCCA BREVIPES (EUPHORBIACEAE): A NEW COMBINATION
}

\author{
P.C. VAN WELZEN \& S.E.C. SIERRA \\ Nationaal Herbarium Nederland, Universiteit Leiden branch, \\ P.O. Box 9514, 2300 RA Leiden, The Netherlands \\ e-mail:welzen@nhn.leidenuniv.nl; sierra@nhn.leidenuniv.nl
}

\begin{abstract}
SUMMARY
Lasiococca brevipes (Merr.) Welzen \& S.E.C. Sierra is a new combination based on Mallotus brevipes Merr. The new combination replaces Lasiococca malaccensis Airy Shaw, which appears to be a later synonym. The species is very rare, but widespread and seemingly with a very disjunct distribution, found in Sumatra, the Philippines, Sulawesi, and the Lesser Sunda Islands.
\end{abstract}

Key words: Lasiococcus, Euphorbiaceae, Malesia, Philippines.

\section{INTRODUCTION}

A recent revision of Mallotus Lour. (Euphorbiaceae) resulted in finding a few odd Philippine specimens, identified under various names: Mallotus resinosus (Blanco) Merr., Mallotus muricatus Müll.Arg. (name a synonym of M. resinosus), and Mallotus brevipes Merr. The material identified as M. muricatus (R.S. Williams 2968) appeared to be isotypes of M. brevipes (Merrill, 1914).

The specimens have whorled to subopposite leaves (terminal leaves opposite), they lack glandular and stellate hairs (typical for Mallotus), the petiole is very short, the leaf base narrowly heart-shaped, and the ovary/fruits have short papillae with a single to a few long, sharp pointed hairs. The specimens with staminate flowers show branching stamens. This combination of characters is typical for Lasiococca Hook.f.

Lasiococca was recently revised (Van Welzen, 1998). The genus is difficult to recognise, a synonym of L. comberi Haines was even described in the Celastraceae: Euonymus auriculatus Craib (Van Welzen, 2002). In Malesia only a single species is known, L. malaccensis Airy Shaw (1968), of which material is very scarce: the type specimen from the Malay Peninsula, and two sterile specimens from Sulawesi and the Lesser Sunda Islands in Indonesia. The Philippine material (four specimens from Mindanao) fits nicely in this distribution, and all specimens have the character typical for L. malaccensis: hair tuft domatia. However, most of the Philippine specimens deviate somewhat, the branches and petioles are hairy (subglabrous in the non-Philippine specimens), the leaves are smaller, the pistillate sepals somewhat smaller, and the pistillate pedicels much shorter. Two specimens bridge the gap: BS (Mesa) 27500 and FB (Miranda) 18270. Both have larger leaves and the former is also subglabrous. This only leaves the pistillate characters for species delimitation (staminate flowers and fruits were still unknown for L. malaccensis), and these differences can just be due to geographic variance. 
Thus, Mallotus brevipes is synonymised with Lasiococca malaccensis. The epithet brevipes is older (Merrill, 1914) than malaccensis (Airy Shaw, 1968), but M. brevipes Merr. is seemingly a later homonym of M. brevipes Pax ex Engl. (Engler, 1895; = Acalypha subsessilis Hutch.; see Pax \& Hoffmann, 1914). However, M. brevipes Pax ex Engl. is a nomen nudum, thus invalid and the name M. brevipes Merr. is legitimate and should replace malaccensis. The new combination, together with a complete description, including staminate and fruit details, is given here. The generic description can be found in Van Welzen (1998).

\section{Lasiococca brevipes (Merr.) Welzen \& S.E.C. Sierra, comb. nov.}

Basionym: Mallotus brevipes Merr. (1914) 487; Pax \& K. Hoffm. (1919) 19; Merr. (1923) 432; Airy Shaw (1983) 35. - Type: R.S. Williams 2968 (holo PNH†; iso NY, 2 sheets), Philippines, SE Mindanao, Davao Prov., between Digas and Santa Cruz.

Lasiococca malaccensis Airy Shaw (1968) 406; Whitmore (1973) 104. - Type: SF (Kiah) 37231 (holo SING n.v.; iso K n.v., L), Peninsular Malaysia, Malacca, Batang Malakka Forest Reserve. Lasiococca sp.?: Airy Shaw (1982) 26, pro bb 26278 (L), Celebes, Ond. Kolaka, Mala-mala.

Tree up to at least $8 \mathrm{~m}$ high; flowering twigs c. $2 \mathrm{~mm}$ thick. Bark smooth, whitish. Stipules c. 2.3 by $0.9 \mathrm{~mm}$. Leaves: petiole $1-4 \mathrm{~mm}$ long, subglabrous; blade obovate, $8-20$ by $2.6-5.7 \mathrm{~cm}$, ratio $3-3.5$, on both sides smooth, glabrous except for hair tuft domatia on lower surface in axils of veins, venation raised on both sides, especially below, with 9-12 pairs of nerves. Staminate inflorescences up to $3 \mathrm{~cm}$ long; bracts broadly ovate, c. 1 by $1.3 \mathrm{~mm}$; bracteoles elliptic, c. 0.8 by $0.3 \mathrm{~mm}$. Staminate flowers c. 5.5 $\mathrm{mm}$ in diameter; pedicel c. $1 \mathrm{~mm}$ long; sepals c. 3.4 by $1.9 \mathrm{~mm}$; androphores up to 4.5 $\mathrm{mm}$ long, anthers c. 0.3 by $0.5 \mathrm{~mm}$. Pistillate flowers: bracts and bracteoles caducous; pedicel $0.8-7 \mathrm{~cm}$ long, (sub)glabrous; flowers $1-1.3 \mathrm{~cm}$ in diameter; sepals 4 or 5 , elliptic, $3.2-8.2$ by $1-3.8 \mathrm{~mm}$, apex cuspidate, subglabrous; pistil c. 3.5 by $2 \mathrm{~mm}$; style $0.5-1.2 \mathrm{~mm}$ long; stigmas c. $1.8 \mathrm{~mm}$ long. Fruits c. 6 by $5 \mathrm{~mm}$, thin-walled; column 4.5-4.8 mm long. Seeds ellipsoid but flattened adaxially, c. 4.8 by 4 by $3.5 \mathrm{~mm}$.

Distribution - Very disjunct in Malesia: Malaysia (Malacca), Philippines (Mindanao), Sulawesi (Sulawesi Tenggara), and Lesser Sunda Islands (Flores).

Habitat \& Ecology - Apparently a very rare species. In Malaysia on hill slopes. Flowering: March to June; fruiting: June.

Vernacular names - Philippines: Talag (Magindanáo; Merrill, 1923). Lesser Sunda Islands: Flores: Mborong.

Note - Philippine specimens with more hairy branches and petioles, usually smaller and relatively broader leaves, shorter pistillate pedicels and sepals.

Specimens studied:

bb series 26278 (Sulawesi); FB series 18270 (Miranda), 27500 (A. de Mesa) (Mindanao); Schmutz 2999 (Timor); SF series 37231 (Malacca); Warburg 14820 (Mindanao); R.S. Williams 2968 (Mindanao).

\section{ACKNOWLEDGEMENTS}

We thank the directors of A, L, NY, and UC for loans and use of their specimens. Jan Frits Veldkamp is thanked for advice on nomenclature. 


\section{REFERENCES}

Airy Shaw, H.K. 1968. Notes on Malesian and other Asiatic Euphorbiaceae. XCIV. Lasiococca Hook.f. in the Malay Peninsula. Kew Bull. 21: 406, 407.

Airy Shaw, H.K. 1982. The Euphorbiaceae of Central Malesia (Celebes, Moluccas, Lesser Sunda Is.). Kew Bull. 37: 1-40.

Airy Shaw, H.K. 1983. An alphabetical enumeration of the Euphorbiaceae of the Philippine Islands: 35. Royal Botanic Gardens, Kew.

Engler, A. 1895. Die Pflanzenwelt Ost-Afrikas und der Nachbargebiete A: 18. Geographische Verlagshandlung Dietrich Reimer, Berlin.

Merrill, E.D. 1914. Notes on Philippine Euphorbiaceae, II. Philipp. J. Sci., Bot. 9: 461-493.

Merrill, E.D. 1923. An enumeration of Philippine flowering plants: 432. Bureau of Printing, Manila.

Pax, F. \& K. Hoffmann. 1914. Euphorbiaceae-Acalypheae-Mercurialinae. In: A. Engler (ed.), Das Pflanzenreich IV.147.vii: 206. Engelmann, Leipzig.

Pax, F. \& K. Hoffmann. 1919. Euphorbiaceae-Additamentum VI. In: A. Engler (ed.), Das Pflanzenreich IV.147.xiv: 19. Engelmann, Leipzig.

Van Welzen, P.C. 1998. Revisions and phylogenies of Malesian Euphorbiaceae: Subtribe Lasiococcinae (Homonoia, Lasiococca, Spathiostemon) and Clonostylis, Ricinus, and Wetria. Blumea 43: 131-164.

Van Welzen, P.C. 2002. The correct interpretation of Euonymus auriculatus Craib (Celastraceae) and Myladenia serrata Airy Shaw (Euphorbiaceae). Nat. Hist. Bull. Siam Soc. 50: 111-114.

Whitmore, T.C. 1973. Tree Flora of Malaya 2: 104, 105. Longman, London. 